\title{
Accommodating the Role of Central Axis Lecturers through the Total Institutional Method in Higher Education
}

\section{Rafdi Rafdi $1^{*}$ \\ 1,2 Akademi Pariwisata - Citra Buana Indonesia, Sukabumi, Indonesia}

\section{A R T I C L E I N F O}

Article history:

Received July 05, 2021

Revised July 07, 2021

Accepted October 24, 2021

Available online November 25, 2021

Kata Kunci :

Untuk Mengakomodasi Dosen

Poros Pusat, Metode Kelembagaan Total

Keywords:

To Accommodate, The Center Axis Lectureers, Total Instititional Method

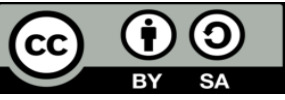

This is an open access article under the CC BY-SA license.

Copyright $@ 2021$ by Author. Published by Universitas Pendidikan Ganesha

\begin{abstract}
A B S T R A K
Kecenderungan kelembagaan total ditandai mulai dari tahapan dan proses pembentukan hingga lahirnya BP3K, yang tahapan dan proses tersebut meliputi Kompertmentalisasi Metode penelitian yang digunakan adalah metode deskriptif. Penelitian ini bertujuan untuk mengeksplorasi masalah untuk menghasilkan gambaran masalah yang holistik. Dari hasil penelitian mereka yang diistilahkan sebagai dosen poros tengah, kemudian dikelompokkan sekaligus digabung menjadi satu wadah. Wadah yang sesuai dengan ciri dan karakternya merupakan manifestasi yang cenderung ke arah institusi total. manifestasi dari kecenderungan total lembaga yang diberi nama BP3K yaitu Bidang Pengembangan dan Pengawasan Kurikulum, Resosialisasi, Isolasi, aturan yang sangat mengikat, pengawasan yang ketat, peran regulator/pembina yang terpusat. Kegiatan BP3K berupa kajian dan pelatihan serta kaderisasi sumber daya anggota di bidang kompetensi fungsional dalam ranah Tri Dharma Perguruan Tinggi. Total unsur kelembagaan yang memberikan kontribusi paling besar terhadap manfaat dan dampak BPЗK jika dibandingkan dengan unsur lainnya adalah unsur keterisolasian dan kekuatan pengawas. implikasi dari hasil penelitian, bahwa melalui BP3K menjadikan Perguruan Tinggi sebagai penyelenggara pelatihan karakter dasar bagi dosen perguruan tinggi, informasi dan apresiasi kepada dua tutor dari BP3K sebagai pelaksana tutorial Karakteristik Dasar BP3K juga digunakan sebagai konsultan akreditasi juga sebagai pusat pelatihan berbagai prestasi dan keahlian bagi Perguruan Tinggi.
\end{abstract}

\section{A B S T R A C T}

The tendency of total institutions is marked through starting from the stages and processes of formation to the birth of the BP3K, which these stages and processes include Compertmentalization The research method used is descriptive method. This study aims to explore the problem to produce a holistic description of the problem. From the research results that they are termed the middle axis lecturer. then they are grouped at once combined into a container. A container that is in accordance with their characteristics and character is a manifestation with a tendency towards total institutions. the manifestation of the tendency of the total institution to be named BP3K, namely the Field of Curriculum Development and Supervision, Resocialization, Isolation, very binding rules, tight control, the role of centralized regulator / coach. BP3K activities in the form of studies and training as well as regeneration of member resources in the field of functional competencies in the realm of Tri Dharma Perguruan Tinggi. The total institutional element that contributes the most to the benefits and impacts of BP3K when compared to other elements is the element of isolation and the strength of the supervisor. the implication of the research results, that through BP3K is to make the College as the organizer of basic character training for lecturers of universities, information and appreciation for two tutors from BP3K as tutorial implementers Basic Characteristics $\mathrm{BP} 3 \mathrm{~K}$ is also used as an accreditation consultant as well as a training center for various achievements and expertise for the College.

\section{INTRODUCTION}

Lecturers are the spearhead of the development and achievements of Tri Dharma in higher education (Arwildayanto, 2013; Syakur et al., 2020). In addition to the obligation to organize learning in universities, lecturers also have an obligation to carry out research and community service (As'ari et al., 2016; Karim, 2020). Based on these obligations, lecturers have very complex tasks and functions. In addition to serving in developing the achievements of the Tri Dharma of Higher Education, some lecturers are given additional tasks in carrying out managerial status, namely as structural lecturers (Akilah, 2018; Mularsih \& Aritonang, 2017). Starting from the highest level such as the Rector/Chairman/Director to the lowest level as a Study Program Coordinator or equivalent. Law Number 14 of 2005 concerning Teachers and Lecturers states that lecturers have an important role as stipulated in the Statutes of each university. 
The increase in the scope of Tri Dharma with the expansion of fields as a result of the implementation of regulations has led to the birth of various quality assurance institutions, tracer studies, off-campus learning, and learning outside the study program (Arifin \& Muslim, 2020; Yamin, 2018). However, this increase is not matched by the readiness of human resources who will carry it out. Whereas the readiness of human resources is one of the important things that need to be considered in the grouping of work fields. The readiness of human resources in terms of quantity is still possible to be fulfilled, but in terms of quality it still does not meet the expected qualifications (Agus \& Asiah, 2021; Nofia, 2020). Increasing the coverage of Tri Dharma by expanding its field of work still has problems in terms of staffing. Staffing in educational institutions is a structural management process and is a system whose overall components are interconnected (Fahmiah Akilah, 2018). These problems have resulted in new gaps, as a result of the implementation of the Independent Learning Campus regulation. Even though the goal is quite clear: Learning Out Come for Dharma 1. And downstream for Dharma 2. and Dharma 3. By not discussing it as a hypothetical variable, it is assumed that there are multiple independent variables that affect the quality of higher education human resources to realize achievements. One point of view is to realize achievements through a good, appropriate, and motivating learning process towards results-based improvement (Mubarak et al., 2018; Nofia, 2020).

There are symptoms of Stereotypes that affect the quality of HR (Saiti, 2015; Spencer et al., 2018). Lecturer stereotypes are only for teaching. Structural lecturer stereotypes are only for managing routine and normative activities. Stereotypes are intuitive thinking shortcuts that humans do to simplify complex things and help make decisions quickly (Saiti, 2015; Spencer et al., 2018). The colloquial language for stereotypes is people who rely on their assumptions in perceiving or judging something without analyzing it first. There is a middle axis HR in the context of the role being between the two, teaching lecturers who want to do and be creative beyond their normative role as a teacher but are not channeled. And there are also structural lecturers who have different ideas but are not channeled within the framework of their job as structural due to differences in views with other structures, or because they are not supported by institutional policies. When the structural perception focuses more on operational leadership that has been conceptualized and standardized and is not ready for coincidence, other structural ideas for change are seen as contradictory (Saiti, 2015; Spencer et al., 2018). This fact is what happened to the CBI college based in Sukabumi.

Institutionally, every university must be proactive in responding to various developments that occur (Serpa, 2018). Moreover, the necessity for this attitude has been framed in the form of regulation. The gaps that occur in CBI Higher Education are shown through the poor information possessed by this institution on the development and implications of the Tri Dharma of Higher Education, the unpreparedness of UPPS and PS with national and international competitiveness, weak enthusiasm for change, and the tendency to prefer things as they are. Authentic evidence about all of that is that several MBKM program packages have not been touched at all, such as the eight concepts of free learning applications, marching funds, formulation of L.O., formulation of Road Maps of each dharma, and others. If it drags on, this university will become chronic stagnation, that is, if the vacuum is longer, the more it will be left behind. These gaps require recovery through high doses. Realize to immediately move and change course before chronic stagnation occurs. This research becomes important when the central axis lecturers are expected to be able to initiate it. Generating institutions towards change through the dynamics of management processes that are in contact with each other, especially the touch of the CBI Higher Management foundation level as the highest management.

The Buana Pratama Foundation as the organizer of CBI Higher Education has a one-person Daily Management Board (BPH) structure with one of the tasks of empowering CBI College Human Resources. BPH looks carefully and assumes that they are a prospective group in realizing the various achievements of the institution. Physically they are not yet united, but in value they are in the same framework. They are creative lecturers who are ready to be creative. Creative lecturers are lecturers who are good at looking for something that is useful for many people, innovating in the context of the Tri Dharma of Higher Education (Republica, March 2018). BPH coined the terms DFPT (Central Axis Functional Lecturer) for creative functional lecturers and DSPT (Central Axis Structural Lecturer) for creative structural lecturers. Uniting DFPT with DSPT in the organizational realm is the foundation for establishing their prospective role towards institutional achievements. Regarding where the organizational form is directed, the analysis of the similarity of character and the role of its members as the most elementary capital for the formation of the organization, how their role proceeds in the managerial corridor, and what results can be obtained from the process, is an interrogative formulation that must be answered. The answer to the interrogative is expected to be able to overcome the empirical gap as described above.

It is not easy to find the character of the organization as a place for DFPT and DSPT . This is due to the strength of the values they have and other tendencies that stand out. They have characteristics that are 
required as academic fighters because they are diligent in expressing ideas, are energetic, and want to do something quickly. This is a capital to be accommodated into a special container. The value of the virtue of knowledge and wisdom has several creative strengths, curiosity, love of learning, a critical and open mind, and perspective (Arifin \& Muslim, 2020; Mularsih \& Aritonang, 2017). The special embodiment leads to a kind of organization that with optimal performance with high focus leads to a single point of achievement. Conditioned in a complete system circle. The description of the totality of the system refers to an organization of totality which is referred to as a total institution. Erving Goffman as the originator of the theory of total institutions, explained the characteristics of the totality of the existence of members in this institution: spending maximum time and being concentrated/bound to the institution, minimizing movement for other things, occupying a place/there is a physical container, controlled through strict institutional rules, strong emotional attachment to the institution (Karim, 2020; Mubarak et al., 2018).

The main keyword about total institutions over various other characteristics, is a policy system that is highly adhered to from such a position as a builder or leader to its members (Nasution, 2020; Yusuf \& Arfiansyah, 2021). The policy of the coach or leader comes from total institutional delegation. Total institutions are closed social systems where life is governed by strict norms, rules and schedules, and what happens within them is determined by a single authority whose will is carried out by the staff who enforce the rules (Siregar et al., 2020; Widiyono et al., 2021). DFPT and DSPT are wealth, potential with unstructured capabilities. Taking advantage of it is an advantage in many ways. The side of human resources development and PT CBI that are causal. They must be patented into a snug framework. Based on the study and consideration, it is concluded that the correct answer to their introgressive existence is that they must be accommodated through total institutions. This research is an analysis of the process and dynamics of the accommodation through the total institution of the DFPT and DSPT. Starting from the recruitment process to finding its embodiment into a total institution. The existence, role and function of this total institution will describe the extent to which the achievements in overcoming the gap in CBI Higher Education are empirically as described. Then the various implications found are no less important, namely the various impacts that occur in reality.

The values brought by the total institution are values that are oriented towards change of competition which are not based on formal regulations. However, whether he is able to change the color of the college based on its strength as a creative organization. Thus, the formulation of the problem to be answered in this study is the extent to which the role of the total institution is capable of being a stimulus to increase the affective power of higher education human resources, namely structural lecturers and ordinary lecturers. Does the affective increase also have an impact on cognitive and psychomorphic improvement? If the increase in these three competencies is realized, it will also have an impact on increasing the achievement of higher education institutions. The formulation of higher education achievements according to the MBKM mandate is a standard that is used as a benchmark. This means that the strength of the total institutional stimuli is ultimately able to become a strategic institution in the body of higher education which plays an important role in changing the direction of increasing institutional achievements according to the formulation of achievements mandated by MBKM.

\section{METHODS}

The research design used is an exploratory qualitative design (Bogdan \& Biklen, 1982; Sugiyono, 2014). The main characteristic of qualitative design focuses on understanding the problem in depth / In Dept Analysis. Problems are seen as important, unique, and also between one problem and another has its own characteristics. So the qualitative analysis is not aimed at formulating generalization conclusions, but the extent to which a problem can be explored. The identification is a kind of complete and sharp portrait of an object. Based on a basic understanding of qualitative research, there are various kinds of qualitative research. In this study, a qualitative exploration research model was applied. It is applying the Total Institution theory to problems that rarely occur in higher education, namely the creation of the central axis lecturers to answer the problem of the low responsiveness of structural lecturers and ordinary teaching lecturers to MBKM at CBI tertiary institutions. Population and sample there are 10 populations consisting of 3 DFPT and 7 DSPT. Everything is used as the object of research. The application of the Quota Sampling Method is due to the relatively small number of populations and is located at one locus, namely on the CBI College campus. Data collection techniques through observation to obtain primary data about the performance, process, results of the DFPT and DSPT as a total institution. Through Guided Interviews guided interviews to obtain primary data that serves as a cross check the suitability of the data obtained by observation and Questionnaire. Guided interviews were also used for data collection, as additional data not covered by observations and questionnaires. Questionnaires are used to collect affective-based primary data from DFPT and DSPT. Documentation is used to collect secondary data in the form of various 
documents that have been processed and inventoried in the form of various written forms and pictures. So the documentation here is not in the form of photos or videos.

\section{RESULT AND DISCUSSION}

\section{Results}

Efforts to identify the presence of axis lecturers is a step in the form of a tracer before they are organized. That the phenomenon that appears to give an intrinsic message about some lecturers who are pro-active in providing input and ideas towards the development of CB Higher Education (PT CBI). The reaction arose on the grounds that the existence of PT CBI was deemed to have failed to respond to the latest developments regarding the tri dharma and MBKM. Some of them realized the response in the form of a structured framework of ideas. This phenomenon is very relevant to stimulus-response theory where one can be reactive to empirically observed information and facts. Freedom to Choice on proactive responses to consist of value-based, choose-driven, strategic, and consistent (Mutjaba, 2008, p.4). As Mutjaba explained in the Stimulus-Response Theory above, a person is free to choose to respond proactively within a value framework, driven by choices, strategies, and consistency. The pro-active response in the value framework is vital to research. In terms of the extent to which the strength of the value possessed by the axis lecturer makes him an axis lecturer. The strata measure by borrowing Bloom's Taxonomy is a reference for measuring the strata.

The tracer results show that 80 percent of the axis lecturers have reached the Affective 4/A4 level. The meaning is that they respond proactively because they are already able to compare the values included in the latest Tri Dharma developments which are linked to the values of PT CBI's human resources. It is the ability to analyze the value of MBKM such as Leaning Outcome which is associated with the Industrial Revolution 4.0 and the things that affect it so that it is then compared to how far PT CBI's human resources have gotten there. The assumption of the axis lecturers that the MBKM values by PT CBI's human resources has only been responded to/A2. In fact, if they are not able to analyze the value of MBKM, the value of PT CBI will be identical to that of a PT that is lagging in the future. Based on the facts about the pro-active response of the axis lecturers and the strength of their values, they deserve to be called creative lecturers so that their identity background makes a new identity in the context of this research, namely DFPT and DSPT. The forum for DFPT and DSPT is organized with its own characteristics with a tendency to be full of total institutions. The ideal understanding of a total institution is a place to live and do activities in which a number of individuals in the same situation, disconnected from the wider society for a certain period of time, together carry out a life that is confined and formally regulated (From Kompasiana, 2014). Goffman is the originator of the total institution of empirical cases that are relevant to the total institution based on Goffman's research, namely mental hospitals, prisons, and boarding schools. The description of the existence and characteristics of the total institution is an isolation, tight control, binding rules, role adjustments, and the magnitude of influence that acts as a coach. In the language of boarding schools, this builder is identical to the Father or Mother of the Boarding School. As in other descriptions of the total institution, it is a condition for equality of its members in the context of status in isolated places, the same activities and directed the same thoughts. There is a strict schedule setting, the activity process is organized under tight control. The role of the coach is very urgent to determine the process and goals of the total institution (Juariah, 2019).

It can be concluded and structured in a structural manner that a total institution with its main characteristic is the isolation of places and conditions which before becoming part of a total institution required a process of role adjustment (resocialization) but prior to resocialization required a transition from the previous role so this concept is called compartmentalization. After that, then enter as a member of the isolation with all the rules that are fixed and controlled by the coach. The assumption of a total institution with all its characteristics is applied as a means as well as a strategy for empowering higher education lecturers' human resources. In this case the CBI College has implemented it. The process of forming a total institutional tendency as a place for DFPT and DSPT at PT CBI through the stages, processes, and characteristics as described below.

\section{Compartmentalization}

DFPT and DSPT are conditioned by BPH to play a special role and are separated from other roles with their own characteristics. This division aims to find the true identity of the common values and characters they have. Separated from other roles, including from their role as functional lecturers for lecturers who come from functional, separated from structural roles for lecturers who come from structural and then they are put together. 


\section{Resocialization}

Resocialization or adjustment of roles, identities, new circumstances, after the compartmentalization stage. Some facts show that this stage is the real stage in which a person experiences a total transition. The stage of severe examination for certain total institutional members such as students who have just entered boarding school boarding schools, it is difficult to adjust to new conditions, considering his role at home as a favorite child, free to go anywhere, not many rules like the current situation. The facts that happened to DFPT and DFPT at the resocialization stage were conditioned through dhama 1 deepening training activities with formal meetings twice a week, non-formal meetings were situationally conditioned several times, doing routine tasks and situational tasks. In other situations, it was also asked to what extent the duties and performance of the members were even at home. During the resocialization process, the role of making provisions/regulations, controlling, and training presenters was handled by one person who was called the coach. The impression of being centralized or centered on one point as a span of control is very strong. The assumption that all things go hand in hand and the interrelationships between the various competencies of a person are the reasons that make everything centralized to the coach. Characteristics like this are rarely found in formal organizations because they conflict with the concept of division of labour.

\section{Isolation}

The understanding of isolation is not limited to alienating or separating oneself, but also as a potential for the formation of togetherness values, strong emotional attachments between fellow members. People spend most of their lives living and working with other people in groups. Each of us is a member of many groups including primary groups such as families and close friends,.... (Person Persyth,2020). The isolation stage is the realization of the tendency to form a total institution completely. DFPT and DSPT are institutionalized into one container. Because the direction of the role is more focused on the realm of dharma 1, the name is deliberately made BP3K (Field of Study Development and Curriculum Supervision) PT CBI. As explained by Erving Goffman, there is a certain pattern in educational institutions as a total institutional tendency through the characterization of the protrusion of isolation. Is one that focuses on educational institutions, training, work activities, such as a place of isolated education/isolation dwelling/permanent in one place, and also other forms of education that are permanent in nature (Erving Goffman in Key Sociology concepts, 2015).

BP3K isolation is not isolation in the sense of a container as understanding boarding, but rather on the role and circumstances in which BP3K inhabits a special room as a center for various activities oriented in the form of assessment and training. The assessment and training focuses on dharma 1, based on the curriculum and its development according to MBKM guidelines. Even though the character of learning is andragogy/adult learning, in its implementation many are characterized as student learning. Lots of assignments, discussions, bringing complete ATK, presentations, discussions. At certain times, performance in front of the class for presentations, role plays, or presenting knowledge products is assessed by all members. There are exams at each stage of learning. Assessment of test results is given in the form of a certificate. BP3K members have gone through 4 stages of learning from February 2020 to March 2021, namely certificates in the fields of Cognitive, Psychomotor, Affective, and tutor learning. Until this research was carried out that BP3K was conducting training on BAN PT accreditation materials but not yet at the assessment stage.

\section{Binding Rules}

Various forms of rules are made based on member agreement. The material of the rules is more about disciplinary regulation. Attendance hours, attendance rates, task execution, and various other disciplines are arranged in such a way based on the agreed corridor.

\section{Strict Control}

The control of BP3K activities is quite strict. This can be seen from the various sanctions for disciplinary violations. Such as sanctions for reducing transportation costs if they arrive late, sanctions are not included for certain activities for members who have been absent several times, and even sanctions are issued from members for certain violations.

\section{The Centralized Role of the Coach}

The existence of a coach is the most vital element for the running of BP3K activities and realizing goals. The existence and logic of the existence of the builder: The mentor should ideally come from the higher education structure so that its programs and policies are adhered to. In this case, the role of the BP3K supervisor is BPH. The coach is ideally multi-role due to the interconnectedness of various fields of activity 
to achieve the goal so that it must be held by one hand. The role of the supervisor/BPH towards BP3K as a multi-role includes: Teachers/tutors, together with the head of BP3K as controllers/controllers, as assessors, drafters, and formulate goals to be achieved.

\section{The Existence of BP3K PT CBI}

In addition to the value of success as a form of embodiment for Axis Lecturers, the benefits and impacts of PT CBI's BP3K internally and externally are other potential values. The results and impacts of BP3K internally and externally include: PT CBI through BP3K is the organizer of basic character training for university lecturers in West Java and Banten. The certificate issued is recognized by LLDIKTI WIL.IV as a mandatory requirement for lecturers to apply for the functional position of expert assistant; The BPH / BP3K Advisor and the Head of BP3K received a legality / certificate from the Head of LLDIKTI WIL.IV as a basic tutor for basic character with the theme Higher Order Method for university lecturers in the West Java and Banten regions. As well as a certificate of appreciation for having implemented IHT Basic Character for several universities. The certificate issued by BP3K for the basic character training is recognized as a mandatory requirement for accompanying diplomas for lecturers in applying for the functional position of expert assistant; Until March 2020 BP3K has held Basic Character Training for lecturers from 25 universities in West Java and Banten; BP3K was made by PT CBI as an accreditation consultant and the center for training and scientific transformation of Tri Dharma for PT CBI; Received recognition from Muhammadyah Sukabumi University for his invitation to give as a speaker at the Higher Order Method Material Workshop for his lecturers.

\section{Discussion}

BP3K PT CBI is a forum solution that was formed for Central Axis Lecturers which is a total institutional tendency with high complexity because it contains relevant elements and processes based on the opinion of experts, namely: Compertmentalization, Resocialization, Isolation, Very Binding Rules, Strict Control, Centralized Role Manager/Builder. The elements of isolation and guidance are the elements that contribute the most compared to other elements in realizing the goals and impacts of the total institution or BP3K. BP3K PT CBI carries out its function as an institution for assessment, training, and competency regeneration in various functional fields in the realm of the Tri Dharma of Higher Education. PT CBI through BP3K became the organizer of basic character training which was legitimized by the head of LLDIKTI WIL. IV. Likewise, two tutors from BP3K received legitimacy as well as awards for holding tutorials for lecturers from twenty-five Universities in the West Java and Banten regions. The certificate issued by BP3K for the basic character training is recognized as a mandatory requirement for accompanying diplomas for lecturers in applying for the functional position of expert assistant. Received recognition from the Muhammadiyah University of Sukabumi for providing training with the higher order theme to Muhammadiyah University Lecturers. In addition, BP3K is used as a consultant and training center in the Tri Dharma environment for PT CBI. There is a new, role-based potential power over university lecturers that has so far gone unnoticed. They are the central axis lecturers playing their roles that can improve the affectiveness of structural lecturers and ordinary lecturers. The affective increase also causes an increase in cognitive competence and psychomotor competence, which is shown through improving processes, results, and achievements of the Tri Dharma of Higher Education. This research also has a significant impact as a framework to fill MBKM's mandate. The basic thinking that gave birth to MBKM is freedom of thought, freedom to develop higher education institutions, and freedom not to be too tied to bureaucracy and not rigid in responding to regulations, the role of the central axis lecturer is very significant as one of the one example to be implemented fulfills the MBKM mandate. Empowerment of central axis lecturers through total institutional forums can be utilized as one of the strategies towards higher education to be able to compete at the international level. This is because, as described previously, the competence has been able to reach the outcome level.

Moving on from the main problem that structural lecturers who have been static in responding to the development of MBKM, as well as ordinary teaching lecturers who only carry out routine roles as teachers, but after the birth of BP3K with its existing roles and functions, structural and teaching lecturers were carried away by this influence. Until then the problem that had been going on was answered. That structural lecturers respond to BP3K ideas, adopt and implement various concepts, and participate in mingling together in solving problems related to the MBKM framework. Significant changes in responsiveness and action from structural lecturers and teaching lecturers on the existence of BP3K various achievements that can be achieved according to MBKM demands, such as several lecturers who have started writing articles in the SINTA journal which so far only writes on the local ISSN. Then it has been successfully compiled Road Maps dharma 1 which came out. Is a CPL formulation with Higher Order qualifications. When mapped, the conclusion of the answer framework for the problem is that structural lecturers and teaching 
lecturers have changed significantly related to MBKM. It is responding to information, processing it through a study, then following it up into a result, even to an outcome. Togetherness between BP3K with structural lecturers and teaching lecturers makes a new form of partnership with new achievements at CBI tertiary institutions.

Lecturers are the spearhead of the development and achievements of Tri Dharma in higher education (Arwildayanto, 2013; Syakur et al., 2020). In addition to the obligation to organize learning in universities, lecturers also have an obligation to carry out research and community service (As'ari et al., 2016; Karim, 2020). Based on these obligations, lecturers have very complex tasks and functions. In addition to serving in developing the achievements of the Tri Dharma of Higher Education, some lecturers are given additional tasks in carrying out managerial status, namely as structural lecturers (Akilah, 2018; Mularsih \& Aritonang, 2017). Starting from the highest level such as the Rector/Chairman/Director to the lowest level as a Study Program Coordinator or equivalent. Law Number 14 of 2005 concerning Teachers and Lecturers states that lecturers have an important role as stipulated in the Statutes of each university.

The increase in the scope of Tri Dharma with the expansion of fields as a result of the implementation of regulations has led to the birth of various quality assurance institutions, tracer studies, off-campus learning, and learning outside the study program (Arifin \& Muslim, 2020; Yamin, 2018). However, this increase is not matched by the readiness of human resources who will carry it out. Whereas the readiness of human resources is one of the important things that need to be considered in the grouping of work fields. The readiness of human resources in terms of quantity is still possible to be fulfilled, but in terms of quality it still does not meet the expected qualifications (Agus \& Asiah, 2021; Nofia, 2020). Increasing the coverage of Tri Dharma by expanding its field of work still has problems in terms of staffing. Staffing in educational institutions is a structural management process and is a system whose overall components are interconnected (Fahmiah Akilah, 2018). These problems have resulted in new gaps, as a result of the implementation of the Independent Learning Campus regulation. Even though the goal is quite clear: Learning Out Come for Dharma 1. And downstream for Dharma 2. and Dharma 3. By not discussing it as a hypothetical variable, it is assumed that there are multiple independent variables that affect the quality of higher education human resources to realize achievements. One point of view is to realize achievements through a good, appropriate, and motivating learning process towards results-based improvement (Mubarak et al., 2018; Nofia, 2020).

\section{CONCLUSION}

BP3K PT CBI is a forum solution that was formed for Central Axis Lecturers which is a total institutional tendency with high complexity because it contains relevant elements and processes based on the opinion of experts, namely: Compertmentalization, Resocialization, Isolation, Very Binding Rules, Strict Control, Centralized Role Manager/Builder. The elements of isolation and guidance are the elements that contribute the most compared to other elements in realizing the goals and impacts of the total institution or BP3K. BP3K PT CBI carries out its function as an institution for assessment, training, and competency regeneration in various functional fields in the realm of the Tri Dharma of Higher Education. PT CBI through BP3K became the organizer of basic character training which was legitimized by the head of LLDIKTI WIL. IV. Likewise, two tutors from BP3K received legitimacy as well as awards for holding tutorials for lecturers from twenty-five Universities in the West Java and Banten regions. The certificate issued by BP3K for the basic character training is recognized as a mandatory requirement for accompanying diplomas for lecturers in applying for the functional position of expert assistant. Received recognition from the Muhammadiyah University of Sukabumi for providing training with the higher order theme to Muhammadiyah University Lecturers. In addition, BP3K is used as a consultant and training center in the Tri Dharma environment for PT CBI. There is a new, role-based potential power over university lecturers that has so far gone unnoticed. They are the central axis lecturers playing their roles that can improve the affectiveness of structural lecturers and ordinary lecturers. The affective increase also causes an increase in cognitive competence and psychomotor competence, which is shown through improving processes, results, and achievements of the Tri Dharma of Higher Education. This research also has a significant impact as a framework to fill MBKM's mandate. The basic thinking that gave birth to MBKM is freedom of thought, freedom to develop higher education institutions, and freedom not to be too tied to bureaucracy and not rigid in responding to regulations, the role of the central axis lecturer is very significant as one of the one example to be implemented fulfills the MBKM mandate. Empowerment of central axis lecturers through total institutional forums can be utilized as one of the strategies towards higher education to be able to compete at the international level. This is because, as described previously, the competence has been able to reach the outcome level. 


\section{REFERENCES}

Agus, A. A., \& Asiah, N. (2021). Implementasi Kebijakan Merdeka Belajar-Kampus Merdeka (Studi pada Fakultas Ilmu Sosial dan Hukum Universitas Negeri Makassar). Jurnal Kreatif Online, 9(4), 32-43. https://jurnal.fkip.untad.ac.id/index.php/jko/article/view/1237.

Akilah, F. (2018). Peran Manajemen Sumber Daya Manusia Dalam Lembaga Pendidikan. Adaara: Jurnal Manajemen Pendidikan Islam, 6(1), 518-534. https://www.jurnal.iainbone.ac.id/index.php/adara/article/download/282/202.

Arifin, S., \& Muslim, M. O. H. (2020). Tantangan Implementasi Kebijakan "Merdeka Belajar, Kampus Merdeka" pada Perguruan Tinggi Islam Swasta di Indonesia. Jurnal Pendidikan Islam Al-Ilmi, 3(1). https://core.ac.uk/download/pdf/328159881.pdf.

Arwildayanto. (2013). Manajemen Sumber Daya Manusia Perguruan Tinggi Pendekatan Budaya Kerja Dosen Professional. CV. Alfabeta.

As'ari, A. R., Kurniati, D., Abdullah, A. H., Muksar, M., \& Sudirman, S. (2016). Impact of infusing truth-seeking and open-minded behaviors on mathematical problem-solving. Journal of Social Issues, 72(3). https://doi.org/10.1111/josi.12185.

Bogdan, R., \& Biklen, S. K. (1982). Qualitative Research for Education: An introduction to theory and methods (Third Edit). Allyn and Bacon.

Karim, B. A. (2020). Pendidikan Perguruan Tinggi Era 4.0 Dalam Pandemi Covid-19 (Refleksi Sosiologis). Education and Learning Journal, 1(2), 102-112. https://jurnal.fai.umi.ac.id/index.php/eljour/article/view/54.

Mubarak, M. Z., Zulkifli, Z., \& Halimatussa'diyah, I. (2018). Kebijakan Deradikalisasi Di Perguruan Tinggi: Studi Tentang Efektifitas Kebijakan Perguruan Tinggi Dalam Mencegah Perkembangan Paham Keagamaan Radikal Di Kalangan Mahasiswa (Studi Kasus UI, UGM DAN UIN Maulana Malik Ibrahim Malang). Istiqro, 16(1), 1-28. http://istiqro.kemenag.go.id/index.php/istiqro/article/view/93.

Mularsih, H., \& Aritonang, L. (2017). Profil kualitas layanan jasa pendidikan tinggi perguruan tinggi swasta di Jakarta. Jurnal Muara Ilmu Ekonomi Dan Bisnis, 1(2), 57-67. https://doi.org/10.24912/jmieb.v1i2.896.

Nasution, A. G. J. (2020). Diskursus Merdeka Belajar Perspektif Pendidikan Humanisme. Al-Arabiyah: Jurnal Pendidikan Bahasa Dan Sastra ..., 6(1).

Nofia, N. N. (2020). Analisis Tantangan Implementasi Kebijakan "Merdeka Belajar Kampus Merdeka" Pada Perguruan Tinggi Islam Negeri Di Indonesia. PRODU: Prokurasi Edukasi Jurnal Manajemen Pendidikan Islam, 1(2). https://ejournal.uinib.ac.id/jurnal/index.php/produ/article/view/3328.

Saiti, A. (2015). Conflicts in schools, conflict management styles and the role of the school leader: A study of Greek primary school educators. Educational Management Administration and Leadership, 43(4), 582-609. https://doi.org/10.1177/1741143214523007.

Serpa, S. (2018). On the concept of Total Institution. International Journal of Social Science Studies, 6(9), 31. https://doi.org/10.11114/ijsss.v6i9.3467.

Siregar, N., Sahirah, R., \& Harahap, A. A. (2020). Konsep Kampus Merdeka Belajar Di Era. Fitrah:Journal of Islamic Education, 1(1), 141-157. https://doi.org/10.53802/fitrah.v1i1.13.

Spencer, M. S., Kieffer, E. C., Sinco, B., Piatt, G., Palmisano, G., Hawkins, J., Lebron, A., Espitia, N., Tang, T., Funnell, M., \& Heisler, M. (2018). Outcomes at 18 months from a community health worker and peer leader diabetes self-management program for Latino adults. Diabetes Care, 41(7), 1414-1422. https://doi.org/10.2337/dc17-0978.

Sugiyono. (2014). Metode Penelitian Pendidikan Pendekatan Kuantitatif, Kualitatif, dan R\&D. Alfabeta.

Syakur, A., Susilo, T. A. B., Wike, W., \& Ahmadi, R. (2020). Sustainability of Communication, Organizational Culture, Cooperation, Trust and Leadership Style for Lecturer Commitments in Higher Education. Budapest International Research and Critics Institute (BIRCI-Journal): Humanities and Social Sciences, 3(2), 1325-1335. https://doi.org/10.33258/birci.v3i2.980.

Widiyono, A., Irfana, S., Guru, P., Dasar, S., Islam, U., Ulama, N., \& Belajar, M. (2021). Implementasi Merdeka Belajar melalui Kampus Mengajar Perintis di Sekolah Dasar. Metodik Didaktik : Jurnal Pendidikan Ke-SD-An, 16(2), 102-107. https://doi.org/10.17509/md.v16i2.30125.

Yamin, M. (2018). Kebijakan Literasi Untuk Meningkatkan Produktivitas Publikasi di Perguruan Tinggi. JASPT Uurnal Analisis Sistem Pendidikan Tinggi Indonesia), 2(1), 19-26. https://doi.org/10.36339/jaspt.v2i1.120.

Yusuf, M., \& Arfiansyah, W. (2021). Konsep “Merdeka Belajar” dalam Pandangan Filsafat Konstruktivisme. AL-MURABBI: Jurnal Studi Kependidikan Dan Keislaman, 7(2), 120-133. http://ejournal.kopertais4.or.id/mataraman/index.php/murabbi/article/view/3996. 